\title{
Research on Political Socialization of University Students under New
}

\section{Stage}

\author{
Hailian $\mathrm{Ke}^{1}$, Yongsheng $\mathrm{Chen}^{2}$ and Kang Peng ${ }^{3}$ \\ College of Music ,Jiangxi University of Technology, Nanchang 330098, China
}

Keywords: University students; Political socialization; Characteristics; Political shape

\begin{abstract}
It's the logic beginning to make clear about the connotation and essence of political socialization as well as the content and characteristics of university students' political socialization. The connotation of political socialization has been studied by scholars home and abroad from different angles. Based on research results of other scholars, this paper aims to understand scientific connotation and class essence of political socialization from the interaction between society and its members.
\end{abstract}

\section{Introduction}

Political socialization is an important component of human's socialization as well as important section of political life. Political socialization emerges with the emergence of politics; besides, political socialization of any society has class nature, which represents the interest of ruling class. Political socialization is an important concept of political theory, which was first proposed by David Easton, American politician in 1958, and later it has been spread with a wide application. Research on political socialization at home started late in the 1980s. According to the research, almost all scholars who work on political socialization have defined it since it has been introduced to politics. There hasn't been a unified definition since different people have different opinions. However, it mainly has three opinions toward political socialization on the whole. The first theory is political study. According to this theory, political socialization is the process during which people study political knowledge and skills with the formation of political concept and mode. The second theory is political and cultural inheritance. It says that political socialization is the inheritance of political culture from generation to generation, and it is also the maintaining and transition process of politics and culture. The third theory is political education. That is, political socialization is the process of shaping members' political psychology, political awareness and political characteristic by society. From the perspective of political life, combined with definitions from scholars home and abroad, the paper presents that political socializationwhich is a dialectic process under certain background of social politics and culture. That is, social members accept social political shape, and in turn, their political characteristics are perfected during affecting and transforming social politics.

\section{Methods}

The Third Plenary Session of the $11^{\text {th }}$ Central Committee of the CCP in 1978 has opened a new stage for socialist modern construction. The main characteristic of China's society during this period 
was reform and open up. While absorbing foreign culture, China's society is under social revolution. At present, China is under a stage of rapid social revolution and opening up. Globalization and social transition is objective reality of current construction of socialist modernization, and it is also times background of studying political socialization among university students. Meanwhile, it is also the fundamental reason for promoting the progress of political socialization among university students.

The political socialization among university students is not carried out in vacuum, instead, it is realized by mutual communication with social environment, and it is also influenced and restricted by social reality. In today's world, progress of globalization is accelerated constantly. Leslie Skair, a British socialist, has given an authoritative definition to globalization. That is, globalization is centered on economic globalization, including the basic contents of communication, ecology as well as tourism. It is a social change trend with cultural and social political influence as its direct consequence. Based on economy and technology, globalization is a comprehensive multi-level historical progress, which relates to economy, politics and culture and so on, promoting a huge change on various aspects of social life.

Political socialization of university students under the new age should be related to current international environment, and it should also be related to China's internal social economic, political and cultural situations with respect of national condition. That is, at present, China is under a comprehensive social transition period with sharp development and change, which has provided opportunities as well as challenges for political socialization of university students.

In order to relieve the negative effect on university students' political socialization by globalization and social transition, the progress of political socialization among university students should be promoted vigorously so that advocated socialist politics and culture can be accepted in a most extensive range.

Marx once said that human is an inborn social animal in any case even if he is not inborn political animal as Aristotle said. Human is inborn social animal, and he becomes inborn political animal after entering political society. Human is social animal means that human can only realize his nature after being socialized in the society. Likewise, only in political society, human can become a qualified political citizen with political nature by accepting political education and experiencing political socialization. If socialization is seen as the key of turning human into social man biologically, then political socialization is a necessary way to turning social human into political one. From the perspective of individual, political socialization is a continuous process for social members' political growth and development, including formation and promotion of political characteristic and capability. During the political socialization of college students, students are form particular political characteristic as well as particular political psychology and ideas by acquiring particular political knowledge from families, schools and social education. Besides, college students' understanding and mastery of political life rules, skills and qualities is the process of forming and promoting their political capabilities. All of these activities are promoted, implemented and enforced by political socialization.

In China, college students' political socialization endows individuals with socialist political characteristic as well as capability so that college students can become qualified social citizens politically. Qualified citizens politically mean that they have stable political characteristic and sound political quality. They are highly political socialized people, representing mature political individuals. College students' political socialization aims to cultivate students' socialist democratic political understanding and knowledge, supporting and participating in socialist construction and practice. 
Besides, their ideological and political quality should be raised by cultivating them into constructors and successors of socialist career with Chinese characteristic. If college students cannot complete political socialization successfully, they may have adverse psychology towards social political life. Therefore, political socialization is an important mean to promote college students' psychological adaptation and social adaptive capability with cultivation of sound political characteristic and participation in social political life. College students should exercise their capability of participation. In addition, college students should take active part in various kinds of social practice and activities so as to improve their political practical ability with a better understanding of society during practice. Thus, college students' political socialization possesses are the value functions of cultivating qualified social citizens politically.

College students under the new age have experienced the huge change brought by reform and opening up personally, and they are direct beneficiaries of reform and opening up. Compared to days before reform and opening up, students now have better social environment and even more smooth development. The main stream of college students' political socialization is sound with strong political identification awareness, upright political attitude as well as positive and rational political participation.

Political attitude is college students' evaluation on political phenomena and behavioral inclination formed on the basis of political knowledge. College students' identification and support of political system and social revolution can be presented by their political attitude. In general, college students' current political attitude is upright, which embodies in the following aspects.

Party's leadership and socialist system should be advocated, which supports reform and opening up, and establishes socialist market economy. College students' knowledge and evaluation on Chinese Communist Party's leadership is an important indicator measuring their political socialization level. According to the investigation in 2004, nearly $80 \%$ college students identify with a series new theoretical opinions and policies proposed by CCP on the $16^{\text {th }}$ National Congress. They identified the essence of "Three Representatives", that is, CCP is a party serving the interests of people and governing for people. $72 \%$ students agree that it is needed to insist the leading position of Marxism in ideological field. They approve of the leading position of CCP in China. According to a rolling survey on college students' ideological and political conditions in 2006, government and the Party's work in that year was highly praised by students, within which, $76.3 \%$ students think the Party and the government achieved significant results in terms of diplomatic relations. Most students keep a clear mind and attitude toward basic political attitudes, for example, it is needed to insist Communist Party's leadership and socialist system, insist the leading position of Marxism in ideological field. In addition, $89 \%$ students believe CCP is the leading core of socialist caused with Chinese characteristic. From the results of investigation and statistics between 2002 and 2006, proportion on this aspect presented an increasing trend. Also, the rolling investigation result of college students' ideological and political conditions in 2007 showed that they had a universal attitude toward CCP, that is, it has the capability to build a sound construction for itself since it is the leading core of socialist caused with Chinese characteristics. According to these investigations, students support Party's leadership and socialist system with active support and strong identification on central guidelines and policies.

College students' participation in political affairs means that students participate in actual affairs by various means based on the knowledge about political and social life. Due to their special age period as well as different living environment from the society, their concrete political participation 
behaviors mainly manifest in concerns about politics and participation in political organizations. At present, college students in China have a positive and rational political participation on the whole.

Joining the CCP is a collective manifestation of college students' participation in political affairs. At present, college students have an increasingly higher initiative for the participation of CCP. It is investigated that students' Party construction has always been seen as important of moral work in universities. One of the very first educational contents that freshmen accept after their admission is basic knowledge about the Party. It is a basic system of universities for leaders from school Party Committee to give Party lessons to students personally. Through education on Party, there has been an increasingly number of freshmen who can be admitted to the Party. Students from some departments even reach over 58\%. By far, there have been totally $48.6 \%$ students submitted applications for Party admission. 23.2\% students have been admitted to the Party. According to statistics from Ministry of Education, proportion of undergraduate Party members has been raised to $8 \%$ from the previous $4 \%$ in the middle of 1990 s. The proportion of undergraduate Party members has reached to $14.5 \%$ by taking Fudan University and Chongqing Jiaotong University as examples. Proportion of Party members among college and university students in Tianjin is 14.9 among the overall students, within which proportion of graduate Party members reaches $40.7 \%$. Meanwhile, active applicants also increase constantly. For example, proportions of applicants in Northwestern Polytechnical University, China University of Geosciences and Chongqing Jiaotong University account between $60 \%$ to $80 \%$. The latest data counted inside the Party in 2006 issued by Central Organization Department shows that student Party members have an obvious increase with an increase of 126 thousand compared to last year. Besides, young people have an even more active enthusiasm in joining the Party. In 2001, the People's University developed 411 student Party members, and the number increased to 1,428 in 2006. Meanwhile, students have had a higher initiative of joining the Party. In 2001, the number of the activists who accepted Party training were 1011, while the amount has raised to 5,494 in 2006. Undeniably, more and more ambitious university students would like to realize their dreams by joining the Party. Besides, they have a deeper identity with Party's governing ideas as well as deeper confidence in China's future.

College students take active part in social practical activities as well as young volunteer service activities, which are the major manifestation of their participation in political affairs. Today, there are millions of young college students participating in the social practical activities, such as "going to the countryside" which was first implementationed in 1997. The constant enthusiasm has warmed farmers and made college students be more responsible. Since the implementation of "Trans-century Youth Civilization Project" in 1993, "Chinese Young Volunteers" action has covered 30 provinces, autonomous regions and municipal cities nationwide. There are millions of college students participating in voluntary work with the formation of tens of thousands of volunteer service teams. Therefore, current college students have a stronger awareness of participating in political activities with higher enthusiasm. Meanwhile, it also embodies the collective feature of college students' political participation.

\section{Conclusions}

Constant individual "internalization" can make college students accept social and political education then make them become qualified political citizens Thus, in order to realize political socialization and optimize its effect, students should give play to their own efforts and improve subjective consciousness of political socialization. 
Clarify the goal of social and political characters, and cultivate sense of political responsibility and mission.

Constantly improve cultural quality as well as political and theoretical quality by hardworking.

Regulate and control political psychology, and overcome crisis of political identity.

Cultivate behavioral capability of democratic politics, and standardize political behaviors.

The political socialization among college students is related to Chinese socialism, so families, schools, society as well as students themselves should make joint effort so that college students of China can be cultivated into qualified political citizens who meet the need of socialist modernization construction, which is beneficial for the development of socialist modernization construction cause.

\section{References}

[1] Habermas J, Habermas J. Toward a rational society: Student protest, science, and politics[M]. Beacon Press, 1971.

[2] Bond M H, Cheung T S. College Students' Spontaneous Self-Concept The Effect of Culture among Respondents in Hong Kong, Japan, and the United States[J]. Journal of Cross-Cultural Psychology, 1983, 14(2): 153-171.

[3] Zeichner K. The new scholarship in teacher education[J]. Educational Researcher, 1999, 28(9): 4-15.

[4] Zeichner K. The new scholarship in teacher education[J]. Educational Researcher, 1999, 28(9): 4-15.

[5] Ward S. Consumer socialization[J]. Journal of consumer research, 1974: 1-14.

[6] Race, class, and power in Brazil[M]. CAAS Publications University of California Los Angeles, 1985.

[7] McDevitt M, Chaffee S. From top-down to trickle-up influence: Revisiting assumptions about the family in political socialization[J]. Political Communication, 2002, 19(3): 281-301.

[8] Ridley C P, Godwin P H B, Doolin D J. The making of a model citizen in communist China[M]. Hoover Institution Press, 1971.

[9] Gauthier M. The inadequacy of concepts: the rise of youth interest in civic participation in Quebec [1][J]. Journal of youth studies, 2003, 6(3): 265-276.

[10] Offe C. New social movements: challenging the boundaries of institutional politics[J]. Social research, 1985: 817-868. 